\title{
VERGILIO FERREIRA: INQUIETAÇÂO E DESASSOSSEGO BREVE APRESENTAÇÃO DE UMA JUSTA HOMENAGEM
}

\author{
Prof. Dr. Jorge Vicente Valentim (UFSCar)
}

\author{
"É-me absolutamente insuportável, primário, \\ infantil um romance que me conte ainda uma \\ 'história'. E atinge as raias do asco que ainda me \\ descrevam, me façam um relatório da boca, dos \\ cabelos e outros fragmentos de uma personagem. \\ Contar histórias é para as avozinhas. Intolerável. \\ Um romance tem é de fixar o que excede a \\ história, a atmosfera que a envolve, o espírito \\ subtil que de tudo emana, o indício das coisas, \\ aquilo que se toca quando se toca a dedos breves \\ como numa brasa, o que aponta ao subentendido, \\ a fina inteligência que assim anima tudo por \\ dentro." \\ [VERGÍLIO FERREIRA. CONTA-CORRENTE 2]
}

Em janeiro de 2016, em Gouveia, uma pequena cidade do Distrito da Guarda, Portugal, nascia Vergílio Ferreira, escritor que, definitivamente, marcou a literatura portuguesa do século XX. Como ficcionista, tradutor e ensaísta, deixou uma obra de inquestionável e inesgotável valor. Títulos como $O$ caminho fica longe (1943) - seu primeiro romance publicado em vida -, Mudança (1949), Aparição (1959), Alegria Breve (1965), Para Sempre (1983) e Em nome da terra (1990), dentre outros, constituem um repertório que, na concepçáo de Eduardo Lourenço, integram uma inequívoca metamorfose, onde "o alarme, inquietude, ou pânico diante da nossa condiçáo mortal, ascende até ao júbilo, até à fruição daquilo que nessa condição é o mais inaceitável ou mais precário, a marca da nossa contingência, o nosso corpo, cenário e lugar de humilhaçóes quotidianas, a cada hora lembrando-nos sem equívoco que náo somos deuses" (LOURENÇO, 1994, p. 123).

Longe, portanto, de ser um escritor movido por questôes de modismos ou acomodaçôes mercadológicas, Vergílio Ferreira foi um artista da inquietude e do desassossego - lembrando, aqui, uma expressão pessoana, de quem ele também foi um sensível leitor - sem temores ou pudores de expressar e transmitir tais sentimentos aos seus 
leitores. A sua conhecida acidez em demonstrar sua forma de pensamento e suas idéias de criação nas pautas diarísticas de Conta-corrente bem delineiam a sua concepção de ver, entender e representar o mundo fora dos eixos confortáveis dos lugares-comuns.

Neste sentido, os textos contidos nesse dossiê vêm, em boa hora, homenagear o autor de Aparição (1959), no conjunto das efemérides do Centenário de Nascimento de Vergílio Ferreira (1916-2016). Ora, numa breve visada sobre os ensaios aqui coligidos, seja numa perspectiva comparatista, como fazem Ana Carla Ferri, Carlos Roberto dos Santos Menezes, Isabel Cristina Rodrigues e Maria Lúcia Dal Farra, em propostas instigantes e sedutoras de leitura do texto vergiliano em diálogo com os de Fernando Namora, Augusto Abelaira, José Saramago e Herberto Helder, respectivamente; seja numa perspectiva mais centralizada em obras específicas, como fazem Maira Contrucci Jamel, Mariana Marques de Oliveira e Madalena Vaz Pinto, que se debruçam sobre romances como Mudança (1949) e Em nome da terra (1992), o leitor tem aqui a oportunidade de vislumbrar algumas das facetas de Vergílio Ferreira e suas ligaçôes com as mais distintas vertentes estéticas e literárias de sua época.

Homem das Letras, marcado pelo "desregramento e o desvario ditados pela descoberta da ausência de razoamento da vida”, como dirá Maria Lucia Dal Farra, Vergílio Ferreira surge nesse conjunto de ensaios como um artista multímodo, lido por diferentes lentes e de diferentes geraçóes. Vale destacar que, malgrado os ditames de certas pautas editoriais, o nosso autor não permaneceu no silêncio e vem despertando a atenção e a curiosidade de inúmeros investigadores, no ensaísmo e nos estudos literários, sobretudo, os de língua portuguesa.

Se, como propôs Vergílio Ferreira, "a obra de arte é uma procura incansável do que nunca se encontrou" (FERREIRA, 1981, p. 175), então, estamos todos definitivamente cativados e seduzidos pela sua poética do desassossego e do assombro, afinal, o que é este conjunto de reflexốes se não a prova definitiva de que estamos todos à deriva e à procura de algo que ainda não alcançamos? E, talvez, porque nunca chegaremos a um termo, continuamos todos colocando em prática o exercício da consciência e da interrogação, táo defendido pelo autor aqui homenageado. Que assim seja e que outros venham.

\section{REFERENCIAS BIBLIOGRÁFICAS}

FERREIRA, Vergílio. Conta-corrente 2. Amadora: Bertrand, 1981.

LOURENÇO, Eduardo. O canto do signo. Existência e literatura (1957-1993). Lisboa: Presença, 1994. 